\title{
Reliability of Interference Pattern on Laryngeal Electromyography for Prediction of Prognosis of Vocal Fold Paralysis
}

\author{
Kwang Ha Moon, Na Rae Oh, Min Kwan Baek, Dong Young Kim, and Joo Hyun Woo \\ Department of Otorhinolaryngology-Head and Neck Surgery, School of Medicine, Gachon University, Gil Medical Center, \\ Incheon, Korea
}

\section{성대마비 예후판단을 위한 후두 근전도 간섭파형의 신뢰도 평가}

문광하 · 오나래 · 백민관 · 김동영 · 우주현

가천대학교 의과대학 이비인후과학교실

Received August 4, 2017

Revised October 18, 2017

Accepted October 18, 2017

Address for correspondence

Joo Hyun Woo, MD, PhD

Department of Otorhinolaryngology-

Head and Neck Surgery,

School of Medicine,

Gachon University,

Gil Medical Center,

38-13 Dockjeom-ro 3beon-gil,

Namdong-gu, Incheon 21565, Korea

Tel +82-32-460-3765

Fax +82-32-467-9044

E-mail woojh@gilhospital.com
Background and Objectives Laryngeal electromyography (LEMG) is valuable for the prognosis of vocal fold paralysis (VFP). However, there is a lack of reliable data to apply it to clinical practice. The aim of this study is to evaluate the reliability of interference pattern of LEMG in order to predict the prognosis of VFP by comparing interference pattern and vocal cord mobility.

Subjects and Method A retrospective chart review was performed for patients who underwent LEMG from January 2012 to October 2015. Gender and age of patients, cause and treatment of VFP, vocal cord mobility, and result of LEMG were analyzed. The interference pattern of LEMG was used as a predictive marker of prognosis, which is compared with vocal cord mobility during the last follow-up.

Results Fifteen patients were enrolled in this study. Among them, five patients were predicted by LEMG evaluation to have good prognosis, and 10 patients were predicted to have poor prognosis. All of the five patients with good prognosis showed improvement in vocal cord mobility, while seven out of 10 patients predicted with bad prognosis showed vocal fold fixation at the last follow-up. The reliability of prognostic prediction through interference pattern was $80 \%$.

Conclusion Interference pattern of LEMG is reliable data to predict the prognosis of VFP, especially it showed perfect consistency for good prognosis.

Korean J Otorhinolaryngol-Head Neck Surg 2018;61(3):143-7

Key Words Electromyography $\cdot$ Interference $\cdot$ Prognosis $\cdot$ Vocal fold paralysis.

\section{서 론}

성대마비는 신경학적인 원인에 의한 성대운동장애를 의미 하는 용어로 사용되고 있으며 외상, 감염, 신경계 질환, 종양,

This is an Open Access article distributed under the terms of the Creative Commons Attribution Non-Commercial License (http://creativecommons.org/licenses/by-nc/4.0) which permits unrestricted non-commercial use, distribution, and reproduction in any medium, provided the original work is properly cited.
갑상선 질환, 자가면역 질환, 의인성 등 다양한 원인이 있을 수 있다. ${ }^{1,2}$

진단을 위해 강직 내시경, 굴곡형 내시경, 후두 스트로보 스코피 등을 통해 성대운동을 관찰하며, 후두 근전도를 이 용하여 신경손상을 객관적으로 증명할 수 있다.3) 후두 근전 도 검사는 후두 근육과 신경의 통합적 기능 상태를 평가하는 검사로 1944년 Weddell 등헤 에 의해 처음 소개되었고 1950년 
대에 Faaborg-Anderson과 Buchthal ${ }^{5}$ 의 연구들로 많은 발 전을 이루게 되었다. 후두 근전도는 성대마비를 진단하고 성 대의 운동장애가 성대마비에 의한 것인지 성대 고정에 의한 것인지를 감별할 수 있으며, 예후를 예측하여 치료 방법을 결정하는 데 중요한 정보를 제공하고 있다. ${ }^{6}$ 하지만 후두 근 전도 검사 방법, 판독, 타당성, 임상 적용 등이 규격화되어 있 지 않고 정확한 안내 지침이 부족하다. ${ }^{67)}$ 그러한 이유로 후두 근전도가 도입된 지 60년이 지났음에도 불구하고 이비인후과 에서 임상적으로 활발하게 이용되지는 못하고 있으며 후두 근전도의 평가항목에 대한 신뢰성 있는 자료가 부족한 실정 이다. 이에 저자들은 후두 근전도 간섭파형과 성대운동 상태 를 비교하여 성대마비 예후판정에 대한 후두 근전도의 신뢰 성을 평가하고자 하였다.

\section{대상 및 방법}

2012년 1월부터 2015년 10월까지 약 3년간 본원 이비인후 과에서 성대마비로 진단되어 후두 근전도를 시행한 환자를 대상으로 하였다. 후두 근전도 후 성대운동에 대한 추적관찰 이 이루어지지 못한 환자들은 배제되었다. 후향적인 차트 분 석을 통해 환자의 나이, 성별, 과거력, 초기 성대운동성, 후두 근전도파형, 근전도에 따른 예후 예측, 추적관찰 후 성대운 동성을 조사하였다. 모든 연구 과정은 기관 윤리심의위원회 승 인을 얻었다(GAIRB2017-260).

성대마비의 진단은 굴곡형 후두 내시경을 이용하였으며, 코 를 통해 숨을 들이마시게(sniff inspiration) 한 뒤 /에/ 발성을 통해 성대 및 피열연골의 움직임을 확인하였다.

후두 근전도는 한 명의 후두전문의에 의해 시행되었다. 환 자가 앙와위를 취한 후 경부를 약간 신전시킨 상태에서 검사 를 시행하였다. 검사는 건측을 먼저 시행 후 환측을 검사하 였으며 건측과 환측을 비교하여 파형을 분석하였다. 26게이 지 단극 침전극을 사용하였으며, 윤상연골 상연 정중선으로 부터 $0.5 \mathrm{~cm}$ 정도 외측에서 윤상갑상막으로 전극을 삽입하 였다. 이후 $30 \sim 45^{\circ}$ 상외측 방향으로 1 2 cm 정도 전진하여 갑 상피열근에 대한 삽입전위, 자발전위, 유발전위를 관찰하였 다. 환측의 유발전위가 건측과 동일한 간섭양상과 진폭을 가 지면 '정상'(Fig. 1A), 간섭파형 감소양상(picket fence pattern) 을 보이면 '불완전마비'(Fig. 1B), 간섭파형이 관찰되지 않을 경우 ‘완전마비'(Fig. 1C)로 분류하였다. 정상 및 불완전마비 를 예후 좋음(favor)으로 판정하였고 완전마비는 예후 나쁨 (poor)으로 판정하였다.

성대운동성은 3 가지로 분류하였으며, '완전 회복'은 건측과 동일한 운동성을 보일 때, '부분 회복'은 성대의 운동성이 호
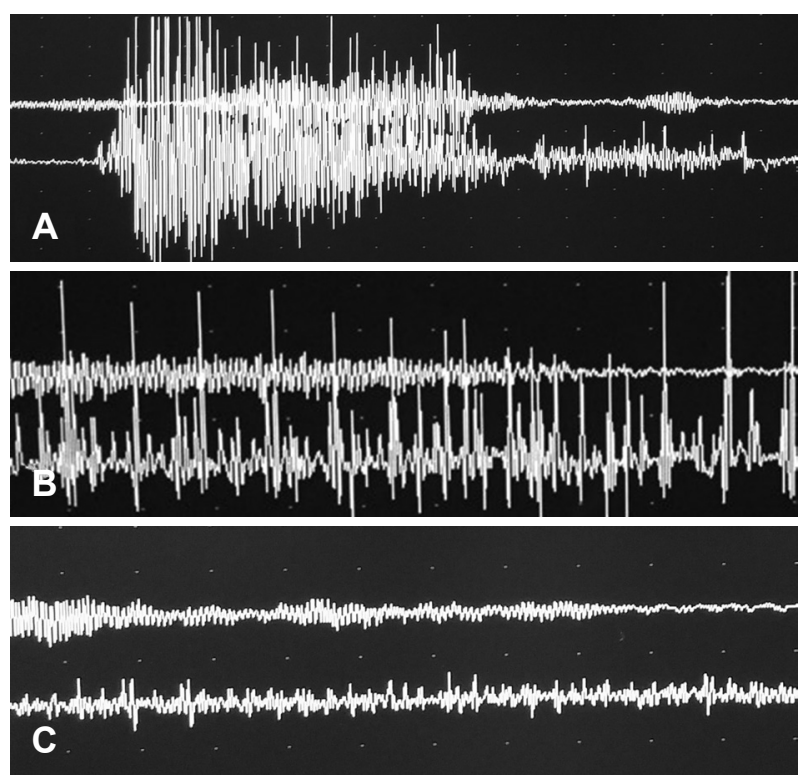

Fig. 1. Laryngeal electromyography patterns. Normal interference pattern (A). Decrease of interference pattern (picket fence) (B). No wave (electrical silence) during phonation (C).

전되었지만 건측에 비하여 감소된 상태일 때, '고정'은 최초 진단 시처럼 성대가 움직이지 않을 때로 분류하였다. 후두 근전도 소견과 외래 추적관찰 중의 성대운동성을 비교하여 후두 근전도에 의한 예후 예측도를 측정하였으며 간섭파형 과 성대운동성 간의 연관성을 측정하였다. 통계분석은 SPSS version 18(SPSS Inc., Chicago, IL, USA)의 Pearson's correlation coefficient를 이용하여 유의성을 분석하였다.

\section{결 과}

기간 중 총 34 명의 환자가 일측성 성대마비로 진단되어 후 두 근전도를 시행받았다. 추적관찰 기간 중 19 명의 환자가 배 제되었으며 15 명이 연구에 포함되었다. 배제 원인은 3명이 피 열연골내전술을 시행받아 영구적으로 성대가 고정되었으며, 1 명은 후두 전절제술을 시행받았고, 1 명은 성문하 협착에 의 한 후두 고정으로 진단되었으며, 3명은 사망하였고, 3명은 최 초 후두 근전도를 시행하였을 때 정상 간섭파형을 보여 배제 하였으며, 8 명은 6개월까지 추적관찰이 이루어지지 못하였다.

남자는 11 명 여자는 4명으로 남녀 비율은 2.75:1이었고 평 균 나이는 54.9세였다. 성대마비의 위치는 우측 4예, 좌측 11 예였으며 추적관찰 기간은 평균 16.2개월이었다(Table 1).

성대마비의 원인으로는 원인 불명, 특발성(idiopathic)이 4 예가 있었으며, 의인성(iatrogenic) 4 예의 원인으로는 갑상선 절제술, 식도절제술, 종격동임파선절제술 등이 있었다. 심경부 감염, 대상포진 바이러스 감염, 람세이-헌트(Ramsay-Hunt) 
증후군 등 감염에 의한 발병이 3예, 폐암, 종격동 $\mathrm{B}-$ 세포 림 프종, 갑상선암 등 악성종양의 진행 및 침범에 의한 것이 3예 있었다(Table 2).

15 명 중 후두 근전도를 시행하였을 때 양호한 예후가 예상

Table 1. Demography of patients

\begin{tabular}{lc}
\hline Total patients $(\mathrm{n})$ & 34 \\
\hline Excluded patients $(\mathrm{n})$ & 8 \\
F/U loss & 4 \\
Operation & 3 \\
Expire & 3 \\
Normal LEMG & 1 \\
$\quad$ Other & 19 \\
\hline Total & 15 \\
\hline Included patients $(\mathrm{n})$ & $11 / 4$ \\
Gender, male/female $(\mathrm{n})$ & $54.9( \pm 13.53)$ \\
Age (years, mean \pm SD) & $4 / 11$ \\
Site, right/left $(\mathrm{n})$ & $16.2( \pm 11.8)$ \\
Follow-up (months, mean \pm SD)
\end{tabular}

F/U loss: loss of following-up, LEMG: laryngeal electromyography

Table 2. Cause of vocal fold paralysis

\begin{tabular}{lll}
\hline Idiopathic & Unknown & $4(27 \%)$ \\
latrogenic & Thyroidectomy & $2(13 \%)$ \\
& Esophagectomy & $1(7 \%)$ \\
& $\begin{array}{l}\text { Mediastinal lymph node } \\
\text { dissection }\end{array}$ & $1(7 \%)$ \\
Infection & Varicellar zoster infection & $2(13 \%)$ \\
& Deep neck infection & $1(7 \%)$ \\
Cancer invasion & Thyroid cancer & $1(7 \%)$ \\
& Mediastinal B-cell lymphoma & $1(7 \%)$ \\
& Uterus cancer & $1(7 \%)$ \\
Trauma & Tracheal rupture & $1(7 \%)$ \\
\hline Total & & $15(100 \%)$ \\
\hline
\end{tabular}

되는 환자는 5 명으로, 후두 근전도에서 감소된 간섭파형을 보 였다. 나머지 10 명은 후두 근전도에서 간섭파형이 관찰되지 않 아 불량한 예후가 예상되었다.

후두 근전도에서 양호한 예후가 예상되었던 5명 중 추적 관찰 중에 성대운동성이 부분 회복된 군이 3 명, 완전 회복된 군이 2 명이었으며, 예후가 좋을 것으로 예상되었던 대상 중 호전되지 않은 대상은 없었다.

예후가 좋지 않을 것으로 예상되었던 10명 중 7 명은 6 개월 이상의 마지막 추적관찰 중에도 성대운동성의 호전이 없었 으며, 나머지 3명은 ‘완전 회복'되었다. 최초 후두 근전도 결과 에서 예상되는 예후와 6개월 이상 추적관찰 후 실제 호전도 의 일치도는 $80 \%$ 를 보였다(Table 3).

원인에 따른 후두 근전도 소견과 성대운동성 회복 여부를 비교해 보았을 때, 원인이 암종 침습과 외상인 경우 $100 \%$ 의 일치율을 보였지만 그 이외의 원인들에서는 $66.7 \%$ 에서부터 $75 \%$ 의 일치율을 보였다. 하지만 증례의 수가 적어 원인에 따 른 후두 근전도의 예후 예측에 차이가 있는지 의미를 부여하 기는 어려웠다(Table 4).

Table 3. Prognostic accordance between prediction though laryngeal electromyography and vocal cord mobility the last following up

\begin{tabular}{|c|c|c|c|c|}
\hline Progn & EMG (n) & Recovery & $C M(n)$ & Accordance \\
\hline Favor & 5 & Full & 2 & $5 / 5$ \\
\hline & & Partial & 3 & \\
\hline & & None & 0 & \\
\hline Poor & 10 & Full & 3 & $7 / 10$ \\
\hline & & Partial & 0 & \\
\hline & & None & 7 & \\
\hline Total & & & & $12 / 15(80 \%)$ \\
\hline & & & & PCC: 0.661 \\
\hline & & & & $p=0.007$ \\
\hline
\end{tabular}

LEMG: laryngeal electromyography, VCM: vocal cord mobility, PCC: Pearson's correlation coefficient

Table 4. Prognostic accordance between laryngeal electromyography and vocal cord mobility based cause of vocal fold paralysis

\begin{tabular}{lccc}
\hline Cause $(\mathrm{n})$ & Prognosis by LEMG $(\mathrm{n})$ & Recovery of VCM (n) & Accordance $(\%)$ \\
\hline Idiopathic (4) & Favor (2) & Full (1) & Partial (1) \\
& Poor (2) & None (1) & Full (1) \\
Iatrogenic (4) & Poor (4) & None (3) & 75 \\
Infection (3) & & Full (1) & 66.7 \\
& Favor (1) & Full (1) & None (1) \\
Cancer invasion (3) & Poor (2) & Full (1) & 100 \\
Trauma (1) & Favor (1) & Partial (1) & 100 \\
\hline
\end{tabular}

LEMG: laryngeal electromyography, VCM: vocal cord mobility 


\section{고 찰}

본 연구는 후두 근전도 간섭파형을 분석하여 성대마비 환 자들의 예후를 예측하였고, 6 개월 이상의 경과관찰 후 성대 운동을 확인하여 예후 판정에 대한 후두 근전도의 임상적 유의성을 확인하고자 하였다.

성대마비의 치료 방법은 경과관찰에서부터 음성치료, 성대 주입술, 갑상성형술, 피열연골내전술, 신경재생술 등 다양하 다. 음성 변화, 연하 곤란, 환자의 요구, 전신 상태 등을 고려 하여 치료를 결정하며 예후 또한 치료 방법 선택에 중요한 인 자이다.

성대마비에서 후두 근전도의 예후 측정에 대한 유용성은 비교적 잘 알려져 있다. 하지만 아직 표준화된 정량적인 평가 기준이 정해져 있지 않기 때문에 정성적 평가가 주로 시행되 고 있다. $\mathrm{Woo}^{8)}$ 는 후두 근전도 유발전위 평가에서 간섭파형 이 보이지 않는 '전기적 고요(electrical silence)' 상태라면 예후 가 불량한 것으로 판단하였으며 후두 기능의 회복 가능성이 낮으므로 조기에 제 1 형 갑상성형술, 피열연골내전술 등의 영 구적인 처치를 시행하였다. 하지만 간섭파형이 전기적 고요를 보이더라도 거대다상전위(giant polyphasic potential)가 동 반된다면 중간예후로 분류하고 후두 주입술로 치료하며 3 6 개월 간격으로 후두 근전도의 반복 검사가 필요하다 주장하 였다." 정성분석에는 간섭양상이 주요 판단 요인으로 사용되 고 있으며 수의 수축이 시작되고 강도가 증가되게 되면 많은 운동단위가 점증되어 간섭양상을 만들게 된다. 이런 간섭양 상은 각각의 운동단위 활동전위를 구별할 수 없는 상태로 나 타나게 되는데, 이것이 정상적인 간섭전위이다.10) 신경병변이 있을 때는 점증이 감소되어 피켓펜스(picket fence) 형태의 불 완전한 간섭전위를 일으키거나 전혀 파형이 나타나지 않는 전기적 고요 상태가 된다. 일반적으로 피켓펜스 형태의 파형 이 나타날 때 불완전마비, 전기적 고요 상태가 나타날 때 완 전마비로 평가할 수 있다. 근병변이 있을 때는 정상적인 간섭 전위를 나타내나 진폭이 감소되어 신경병성 질환과 근육병 성 질환을 감별할 수 있다.)

본 연구에서는 성대마비 환자에서 간섭파형을 이용한 예후 예측의 신뢰도를 평가하고자 하였으며 $80 \%$ 의 일치도를 보여 간섭파형을 평가하여 예후를 예측하는 것이 상당히 신뢰할 만 한 것임을 보여주고 있다. ${ }^{11)}$ 단순 추적관찰이나 음성치료 등 의 보존적 치료도 성대마비의 기본 치료로 추천되는 상태에 서 침습적 치료, 특히 비가역적인 치료의 시행 여부를 조기에 결정하기는 쉽지 않다. 특히 심각한 정도의 음성 변화나 연하 곤란을 호소하는 경우 후두 근전도를 이용하여 성대마비의 예후를 측정하는 것이 치료 방법을 결정하기 위한 중요한 정보
를 제공할 수 있다.

본 연구에서 예후와 일치하지 않았던 3명의 환자가 있으며, 이는 모두 후두 근전도 시행 시 간섭파형이 관찰되지 않아 예 후가 불량할 것으로 판단하였으나 추적관찰 후 성대 움직임 이 정상으로 돌아오거나 호전된 경우였다. 이들 세 명의 환자 에서 성대마비의 원인은 각각 대상포진바이러스감염, 폐수술 후 발생한 의인성, 특발성으로 다양하였다. 따라서 후두 근전 도의 간섭파형이 나타나지 않는 전기적 고요를 보이더라도 모두 예후가 불량한 것은 아니므로 비가역적 수술은 신중히 결정되어야 한다. 반면, 후두 근전도에서 예후가 좋을 것으로 판단한 환자들은 모두 성대운동성이 향상되었으며 이러한 결과는 성대마비 환자들에 대한 진료와 상담에서 중요한 정 보를 제공함으로써 환자-의사 관계 형성과 환자의 긍정적 기 다림에 큰 도움이 될 것으로 판단된다.

성대마비 환자에서 후두 근전도의 시행 시기에 대해서는 논 란이 있다. 신경손상 후 발레리안 퇴화(Wallerian degeneration)가 완료되어야 근육의 탈신경 정도가 확인되므로 약 1 주 에서 4 주의 시간이 소요된다. ${ }^{12)}$ 이런 이유로 신경학자들은 병 변의 종류를 감별하고 중증도를 확인하기 위해 신경손상 발 생 후 3주 이후에 근전도 검사를 시행하는 것을 추천하고 있 다. ${ }^{13,14)}$ 하지만 후두 근전도의 경우 신경손상이 발생한 뒤 후 두근의 기능적 약화 이후 구축, 신경재생이 진행되는 데 시간 이 걸리기 때문에 6 8주에 후두 근전도를 시행하는 것이 가 장 정확하다는 주장이 있다. ${ }^{14,15)}$ 저자들은 성대마비 발생 이후 최소 한 달 이후에 후두 근전도를 시행하였다.

본 연구에서는 후두 근전도 간섭파형 분석을 통해 성대마 비의 예후를 예측하고자 하였다. 이는 정성적 분석 방법으로 객관화된 수치를 보여 주지 못하는 한계가 있지만 임상적으 로는 $80 \%$ 의 비교적 신뢰할 만한 예후 예측도를 보였으며, 특 히 후두 근전도에서 좋은 예후가 예측되는 환자들의 신뢰도 는 $100 \%$ 로 환자 관리에 유용한 정보를 제공하는 것으로 밝 혀졌다. 추후 운동단위 활동전위의 정성적 분석을 통하여 성 대마비 환자의 평가에서 후두 근전도의 유용성을 제고하기 위한 연구가 필요할 것으로 생각한다.

\section{REFERENCES}

1) Sulica L, Blitzer A. Vocal fold paresis: evidence and controversies. Curr Opin Otolaryngol Head Neck Surg 2007;15(3):159-62.

2) Simpson CB, Cheung EJ, Jackson CJ. Vocal fold paresis: clinical and electrophysiologic features in a tertiary laryngology practice. J Voice 2009;23(3):396-8.

3) Kim HJ, Park HS, Kim HS, Park KD, Chung SM. Usefulness of the laryngeal electromyography in diagnosis of vocal fold paresis. J Korean Soc Laryngol Phoniatr Logop 2011;22(2):126-32.

4) Weddell G, Feinstein B, Pattle RE. The electrical activity of voluntary muscle in man under normal and pathological conditions. Brain 1944;67(3):178-257. 
5) Faaborg-Andersen K, Buchthal F. Action potentials from internal laryngeal muscles during phonation. Nature 1956;177(4503):340-1.

6) Chung SM. Laryngeal electromyography. J Korean Soc Laryngol Phoniatr Logop 2006;17(1):5-13.

7) Wang CC, Chang MH, De Virgilio A, Jiang RS, Lai HC, Wang CP, et al. Laryngeal electromyography and prognosis of unilateral vocal fold paralysis--a long-term prospective study. Laryngoscope 2015; 125(4):898-903.

8) Woo P. Laryngeal electromyography is a cost-effective clinically useful tool in the evaluation of vocal fold function. Arch Otolaryngol Head Neck Surg 1998;124(4):472-5.

9) Blitzer A, Crumley RL, Dailey SH, Ford CN, Floeter MK, Hillel AD, et al. Recommendations of the Neurolaryngology Study Group on laryngeal electromyography. Otolaryngol Head Neck Surg 2009;140 (6):782-93.
10) Chung SM. Diagnostic laryngeal electromyography. J Korean Soc Laryngol Phoniatr Logop 2008;19(2):107-12.

11) Munin MC, Rosen CA, Zullo T. Utility of laryngeal electromyography in predicting recovery after vocal fold paralysis. Arch Phys Med Rehabil 2003;84(8):1150-3.

12) Feinberg J. EMG: myths and facts. HSS J 2006;2(1):19-21.

13) Schweizer V, Woodson GE, Bertorini TE. Single-fiber electromyography of the laryngeal muscles. Muscle Nerve 1999;22(1):111-4.

14) Pardo-Maza A, García-Lopez I, Santiago-Pérez S, Gavilán J. Laryngeal electromyography for prognosis of vocal fold paralysis. J Voice 2017; 31(1):90-3.

15) Min YB, Finnegan EM, Hoffman HT, Luschei ES, McCulloch TM. A preliminary study of the prognostic role of electromyography in laryngeal paralysis. Otolaryngol Head Neck Surg 1994;111(6):770-5. 